\title{
The Role of Bacterial Biofilms in Ocular Inflammation
}

\author{
Henry Daniel Perry ${ }^{1 *}$ and James M Rynerson ${ }^{2}$ \\ ${ }^{1}$ Department of Ophthalmology, Ophthalmic Consultants of Long Island, USA \\ ${ }^{2}$ Department of Ophthalmology, USA
}

Submission: March 14, 2018; Published: March 20, 2018

*Corresponding author: Henry Daniel Perry, Department of Ophthalmology, Ophthalmic Consultants of Long Island, Ryan Medical Arts Bldg., Ste. 402, Rockville Centre, NY 11570, USA, Email: hankcornea@gmail.com

\section{Editorial}

For several decades, Blephariti, dry eye disease and meibomian gland dysfunction (MGD) have been thought to be three distinct entities, and evaporative dry eye distinct from aqueous insufficiency [1]. To further muddy the discussion, subtle distinctions separate posterior blepharitis and meibomian gland dysfunction (MGD) [2]. Is it possible that all these diseases are really linked by the same pathogenic mechanism? A new theory suggests that these diseases are all connected by a single concept, namely bacterial biofilm formation [3] and that anew term, dry eye blepharitis syndrome (DEBS) would be more accurate and more appropriate terminology. This term explains the relationship between bacterial biofilm formation on the eyelid margin and connects blepharitis, dry eye and MGD as linear changes related to biofilm maturation and migration [4].

First, we must understand that bacteria come in two forms: planktonic, which are individual, free-floating bacteria and biofilm-dwellers, which are bacteria thatproduce and live in a polysaccharide biofilm [5]. In nature, the prevailing habitat of bacteria is not planktonic, but is within a biofilm that they create for themselves. Biofilm is a well-hydrated matrix of bacterial glycocalyx, and is produced by the vast majority of bacterial species, including Staphylococcus [6]. It can be thought of as a layer of protective armor. It is virtually impenetrable, like a fortress. Antibiotics can't penetrate it, a surgical iodine prep can't penetrate it, and believe it or not, our own white cells can't penetrate it [7].

Biofilms will occur anywhere moisture and nutrients exist on a surface [8]. The lid margin with moisture, nutrients and warmth, are the perfect environment for a thriving bacterial biofilm. In fact, it would be unrealistic to suggest that a biofilm does not exist on the lid margin. It probably begins forming just after birth when the lids first become colonized with lid flora [9].

A single bacterium would have a low chance of survival. However, put that bacteria together with billions of others, and the biofilm as a whole, can survive and expand. Bacteria communicate with one another within a biofilm using a chemical called homoserine lactone (HSL) [10]. While the HSL concentrations in the biofilm of a 2-year old child is very low, and hence the biofilm is non-pathogenic, the biofilm of a 50 or 60 year old has had decades to thicken, and increase its bacteria load and HSL concentrations. This is a critical component of the pathogenesis of DEBS.

Once the bacterial colony senses that it numbers have reached critical mass though an increased concentration of HSLs, quorum-sensing gene activation (QSGA) occurs [11]. QSGA occurs when the bacterial population reaches a certain quorum, triggering dormant genes to activate. The newly activated genes now begin expressing inflammatory virulence factors such as lipases, proteases, and cytolytic toxins, among a host of others [12].

Why do bacteria not just start making virulence factors from the beginning? Because bacteria do not want to produce an inflammatory response from the host until they know they can survive it. So the colony waits until they reach a quorum, indicating that they are safe within a thickened biofilm.

It is important to realize that not all strains of Staphylococcus are identical. Some are much more pathogenic than others. Some might create an early mature biofilm together with highly inflammatory toxins producing severe blepharitis and chalazion in an 8 year-old, while others may produce minimal biofilms with relatively mild virulence factors over a person's lifetime, and therefore spare an 80 year-old of any significant lid margin disease. It all depends on the particular strain of staphylococcus [13].

\section{Stages of DEBS}

Stage 1 Folliculitis: Inflammation and edema of the lash follicles. It is always first due to the easy access of the encroaching biofilm down along the lash. Stage One DEBS, occurs especially rapidly in contact lens wearers [14]. 
Stage 2 MGD: Impaction and inflammation of the meibomian gland (MG). Due to the size of the MG relative to the lash follicle and the small ductule with constant efflux of lipids, it simply takes longer for biofilm to accumulate and thicken within the MGs. First, a simple plugging of the MG with altered meibum (raises melting point), reduces the quantity and quality of the meibum, sometimes referred to as non-obvious MGD with minimal inflammation. As the biofilm thickens within the MG, it eventually undergoes quorum-sensing and virulence factor production which causes the inflammation that is referred to as "posterior blepharitis." At this point one will begin to see domes of meibofilm (altered meibum) over each meibomian ductule. It has long been thought that these little cream-colored domes over the MG were "caps" of keratin [15]. But since the posterior lid margin consists of non-keratinized stratified squamous epithelium, this is more likely simply meibofilm (altered meibum).

Stage 3 DEBS: Aqueous insufficiency - inflammation of the accessory lacrimal glands of Krause and Wolfring. It always occurs after MGD.20. This is easy to understand if one reviews the lid anatomy and location of these tear glands. The Glands of Wolfring are located along the top of the tarsal plate, and the Glands of Krause deep within the fornices. These 2 areas are quite distant from the margin, delaying access to a growing biofilm. However, biofilms can "seed" new areas by constantly dispersing tiny bits of biofilm into their environment, in this case the tear film. If this happens hundreds of times a day, for 3050 years, it is not inconceivable that a microscopic bit of biofilm eventually reaches these glands.

We regularly see patients present with watery eyes, difficultly reading for long periods, burning etc, and they are typically difficult to refract as the vision changes with every blink. A low TBUT, few if any meibomian puddles and occluded ducts, confirm the diagnosis of Evaporative Dry Eye disease. But explaining that to the patient can be difficult, as they can't comprehend how they can have dry eye with tears running down their cheek These patients with diseased MG together with healthy lacrimal glands are the most common form of dry eye disease. However, how many times do we see a patient present with the exact opposite scenario...lots of lipids, perhaps a drop of oil running down the cheek, with no aqueous. How many times do we see healthy MG together with aqueous insufficiency? Basically, this does not occur.

So here is the key question: If aqueous insufficiency is truly a separate overlapping disease, wouldn't we expect to see it present occasionally prior to meibomian gland disease? But we never do because it is simply a later stage of the same disease. It does not happen because the morphology and anatomical location of the tear glands preclude it from happening.

Now that we have identified the central problem, certain treatment regimens make more sense. We have always felt lid hygiene should be the cornerstone of any therapy of chronic blepharitis. While advocating salt water soaks may seem superfluous in this day and age it still works [16] and the physician patient conference switches responsibility to the patient; important in a chronic incurable disease [17]. Lid hygiene should begin and be taught in early childhood.

Overall, try rethinking dry eye, as a biofilm problem and this will lead to earlier and more effective treatment paradigms with improved outcomes.

\section{References}

1. Lemp MA (1973) Pathophysiology and diagnosis of tear film abnormalities. Int Ophthalmol Clin 13: 191-197.

2. Dougherty JM, McCulley JP (1984) Comparative bacteriology of chronic blepharitis. Br J Ophthalmol 68(8): 524-528.

3. Lappin-Scott H, Burton S, Stoodley P (2014) Revealing a world of biofilms--the pioneering research of Bill Costerton. Nat Rev Microbiol 12(11): 781-787.

4. Rynerson JM, Perry HD (2016) DEBS a Unification theory for Blepharitis, Meibomian Gland Disease and Dry Eye Disease. Clin Ophthalmol 10: 2455-2467.

5. Christersson LA, Zambon JJ, Genco RJ (1991) Dental bacterial plaques. Nature and role in periodontal disease. J Clin Periodontol 18(6): 441446.

6. Brothers KM, Nau AC, Romanowski EG, Shanks RM (2014) Dexamethasone diffusion across contact lenses is inhibited by Staphylococcus epidermidis biofilms in vitro. Cornea 33(10): 10831087.

7. Monroe D (2007) Looking for chinks in the armor of bacterial biofilms. PLoS Biol 5(11): e307.

8. Absalon C, Van Dellen K, Watnick PI (2011) A communal bacterial adhesin anchors biofilm and bystander cells to surfaces. PLoS Pathog 7(8): e1002210.

9. Viswalingam M, Rauz S, Morlet N, Dart JK (2005) Blepharokeratoconjunctivitis in children: diagnosis and treatment. $\mathrm{Br}$ J Ophthalmol 89(4): 400-403.

10.Zhang C, Zhu S, Jatt AN, Zeng M (2016) Characterization of N-acyl homoserine lactones (AHLs) producing bacteria isolated from vacuum-packaged refrigerated turbot (Scophthalmus maximus) and possible influence of exogenous AHLs on bacterial phenotype. J Gen Appl Microbiol 62(2): 60-67.

11. Hastings JW, Greenberg EP (1999) Quorum sensing: the explanation of a curious phenomenon reveals a common characteristic of bacteria. J Bacteriol 181(9): 2667-2668.

12. Bzdrenga J, Daudé D, Rémy B, Jacquet P, Plener L, et al. (2016) Biotechnological applications of quorum quenching enzymes. Chem Biol Interact 267: 104-115.

13. Edwards AE, Bowden MA, Brown EL, Laabei M, Masey RC (2012) Staphylococcus aureus Extracellular Adherence Protein Triggers TNFa Release, Promoting Attachment to Endothelial Cells via Protein A. PLoS One 7(8): e43046.

14. Killpartrick MR (2016) Disposable lens risk factors and posterior lens surface contamination. Cont Lens Anterior Eye 39(5): 400.

15. Maskin SL (2010) Intraductal meibomian gland probing relieves symptoms of obstructive meibomian gland dysfunction. Cornea 29(10): 1145-1152. 
16. Lindsley K, Matsumura S, Hatef E, Akpek EK (2012) Interventions for chronic blepharitis. Cochrane Database Syst Rev (5): CD005556.

This work is licensed under Creative Commons Attribution 4.0 License

DOI: 10.19080/JOJCS.2018.06.555691
17. Romero JM, Biser SA, Perry HD, Levinson DH, Doshi SJ, et al. (2004) Conservative treatment of meibomian gland dysfunction. Eye Contact Lens 30(1): 14-19.

\section{Your next submission with Juniper Publishers will reach you the below assets}

- Quality Editorial service

- Swift Peer Review

- Reprints availability

- E-prints Service

- Manuscript Podcast for convenient understanding

- Global attainment for your research

- Manuscript accessibility in different formats ( Pdf, E-pub, Full Text, Audio)

- Unceasing customer service

Track the below URL for one-step submission https://juniperpublishers.com/online-submission.php 